\title{
Effect of the aminopeptidase from Pseudomonas fluorescens ATCC 948 on synthetic bitter peptides, bitter hydrolysate of UHT milk proteins and on the ripening of Italian Caciotta type cheese
}

\author{
M Gobbetti 1, L Cossignani 2, MS Simonetti 2, P Damiani 2 \\ 1 Institute of Dairy Microbiology; \\ 2 Institute of Food Chemistry, S Costanzo, 06100 Perugia, Italy
}

(Received 19 October 1994; accepted 4 January 1995)

\begin{abstract}
Summary - The activity of the purified aminopeptidase from Pseudomonas fluorescens ATCC 948 on synthetic bitter peptides, bitter hydrolysate of UHT milk proteins and on the ripening of Italian Caciotta type cheese was studied. The aminopeptidase almost completely hydrolyzed the bitter pentapeptide H-Leu-Trp-Met-Arg-Phe-OH and liberated Val from the bitter tetrapeptide H-Val-Pro-Leu-Leu$\mathrm{OH}$. No cleavage of the Pro-bound was observed. In UHT milk in which bitter protein hydrolysate was caused by externally added proteinase, the aminopeptidase produced a concentration of free amino acids about 8 times higher than those determined on UHT unhydrolyzed non-bitter milk (211.3 vs $25.3 \mu \mathrm{g} / \mathrm{ml}$, respectively). Glu, Leu, Met, Trp and Val were the most abundant amino acids. The enzyme showed $44 \%$ of its maximum activity at the storage temperature of UHT milk $\left(20^{\circ} \mathrm{C}\right)$. The aminopeptidase was stable during the ripening of Caciotta type cheese: no activity was lost during 2 months. After 45 days of ripening, the cheese containing aminopeptidase had a higher amino acid level $(990.2 \mu \mathrm{g} / \mathrm{ml})$ than the untreated-control $(591.1 \mu \mathrm{g} / \mathrm{ml})$. The amino acid profile of the treated cheese reflected the aminopeptidase activity. The specific hydrolysis of peptidic bounds involving amino acids (Leu, Trp and Val), usually identified as major components of bitter peptides, probably indicates a debittering activity of this aminopeptidase.
\end{abstract}

aminopeptidase / bitter peptide / bitter UHT milk / cheese ripening

Résumé - Effet de l'aminopeptidase de Pseudomonas fluorescens ATCC 948 sur les peptides amers synthétiques, les hydrolysats de protéines du lait UHT et sur l'affinage du fromage italien de type caciotta. On a étudié l'activité de l'aminopeptidase purifiée de Pseudomonas fluorescens ATCC 948 sur les peptides amers synthétiques, les hydrolysats amers des protéines du lait UHT et sur l'affinage du fromage italien de type caciotta. L'aminopeptidase a presque totalement hydrolysé le pentapeptide amer H-Leu-Trp-Met-Arg-Phe-OH et libéré Val du tétrapeptide amer H-ValPro-Leu-Leu-OH. Aucun clivage de la liaison Pro n'a été observé. Dans le lait UHT, dans lequel 
I'hydrolyse des protéines a été provoquée par addition d'une protéinase, l'aminopeptidase a produit une concentration d'acides aminés libres environ 8 fois plus élevée que celles déterminées sur le lait UHT non hydrolysé et non amer (211,3 contre $25,3 \mu \mathrm{g} / \mathrm{ml}$ respectivement). Glu, Leu, Met, Trp et Val ont été les plus abondants. L'enzyme a présenté $44 \%$ de son activité maximale à la température de conservation du lait UHT $\left(20^{\circ} \mathrm{C}\right)$. L'aminopeptidase a été stable pendant l'affinage de la caciotta: aucune activité n'a été perdue pendant 2 mois. Au terme de 45 jours d'affinage, le fromage contenant l'aminopeptidase présentait un niveau d'acides aminés plus élevé $(990,2 \mu \mathrm{g} / \mathrm{ml})$ que le contrôle non traité $(591,1 \mu \mathrm{g} / \mathrm{m} /)$. Le profil des acides aminés du fromage traité reflétait l'activité de l'aminopeptidase. L'hydrolyse spécifique des liaisons peptidiques impliquant des acides aminés (Leu, Trp et Val) habituellement identifiés comme étant les principaux composants des peptides amers indique probablement une activité d'élimination de l'amertume de cette aminopeptidase.

aminopeptidase / peptide amer / lait UHT amer / affinage

\section{INTRODUCTION}

While amino acids, amines, amides, substituted amides, long chain ketones and some monoglycerides may also contribute to bitterness (Ney, 1979), it is now accepted that the bitter flavour produced in cheese during the enzymatic hydrolysis of bovine casein is due to some types of peptides (Fujimaki et al, 1970; Lemieux and Simard, 1991, 1992).

The occurrence of bitter flavour in UHT milk has been documented (McKellar, 1981; Sørhaug and Stepaniak, 1993) and attributed to heat-stable proteinases produced by psychrotrophic bacteria. The monitoring of raw milk refrigeration, the use of controlled or modified atmosphere storage of milk, the activation of the inhibitory system (lactoperoxidase) of milk, or the application of low temperature inactivation (LTI) (Skura, 1989) and of UHT modified treatment (Bucky et al, 1988) are proposed for controlling heatstable proteinases from psychrotrophs.

Bitterness has long been recognised as a major defect in Camembert (Pélissier et al, 1974a), Cheddar (Edwards and Kosikowski, 1983), Gouda (Visser et al, 1983), and Gorgonzola (Delformo and Parpani, 1986) cheeses. A combined action of rennet and proteinases from some starter microflora is considered to be the cause of the bitter taste. Several possibilities exist for monitoring bitterness in cheese: 1) selection of starters or cheese-related microorganisms with strong peptidase and, in particular, aminopeptidase activities (Arora and Lee, 1990; El Abboudi et al, 1991); 2) use of mutant proteinasenegative strains and with the same peptidase activity as the parent cell (Kamaly and Marth, 1988); 3) addition of commercial mixture of proteolytic microbial and animal preparation (Fox, 1988); 4) addition of heattreated cultures of lactic acid bacteria (Ardo et al, 1989); and 5) use of exopeptidases from microorganisms other than lactic acid bacteria, such as Bacillus stearothermophilus (Roncari and Zuber, 1970), Brevibacterium linens (Brezina et al, 1988) and Thermus acquaticus (Minagawa, 1989).

Following other investigations (Gobbetti and Rossi, 1992; Gobbetti et al, 1993, 1994), this study examines the activity of a purified aminopeptidase from Pseudomonas fluorescens ATCC 948 on synthetic bitter peptides, bitter hydrolysate of UHT milk proteins and on the ripening of Italian Caciotta type cheese.

\section{MATERIALS AND METHODS}

\section{Enzyme}

The aminopeptidase from Pseudomonas fluorescens ATCC 948 was purified by ion-exchange 
chromatography (DEAE-Sephadex A-50, Pharmacia Fine Chemicals, Uppsala, Sweden), gel filtration (Biogel P-300, Biorad Labs, Richmond CA, USA), affinity chromatography (L-Leu-GlyAH-Sepharose 4B, Pharmacia), and then lyophilized. It was characterized as metalloenzyme with broad specificity, irreversibly inactivated after a heat treatment of $75^{\circ} \mathrm{C}$ for $1 \mathrm{~min}$ and with optimal $\mathrm{pH}$ and temperature at 7.5 and $45^{\circ} \mathrm{C}$, respectively (Gobbetti et al, 1994). The lyophilized preparation had a specific activity of 9.916 units/mg protein. One unit of the aminopeptidase activity was defined as the amount of enzyme needed to increase of 0.01 the absorbance at $560 \mathrm{~nm}$ after $1 \mathrm{~min}$ of incubation.

\section{Measurement of aminopeptidase activity}

The aminopeptidase activity on bitter peptides (BP), on bitter UHT milk with partially hydrolyzed proteins (BHMP) and on the ripening of Italian Caciotta type cheese was determined by the analysis of the individual free amino acids before and after the treatment with the enzyme.

\section{Isolation of the amino acids}

BHMP or Caciotta cheese extracts $(5 \mathrm{ml})$ prepared as described by Desmazeaud and Vassal (1979) were centrifuged at $20000 \mathrm{~g}$ for $20 \mathrm{~min}$. One $\mathrm{ml}$ of the centrifuged sample (containing 0.02 to $1.2 \mathrm{mg} / \mathrm{ml}$ of DL-norleucine as double internal standard, according to the presumed amino acids content) was filtered through a Biogel P2 (400 mesh, column $1 \times 60 \mathrm{~cm}$, Biorad) and eluted with $0.05 \mathrm{~mol} / \mathrm{l}$ phosphate buffer $(\mathrm{pH}$ 7.0). The fraction of eluate between $25-65 \mathrm{ml}$ was collected, adjusted to $\mathrm{pH} 4-5$ and subjected to an ion-exchange purification through an AG 50W-X8 resin (column size $1 \times 12 \mathrm{~cm}$ ) (Biorad). After washing with $45 \mathrm{ml}$ of distilled water, a 40 $\mathrm{ml}$ fraction was eluted with $1 \mathrm{~mol} / \mathrm{l} \mathrm{HCl}$, collected and concentrated to $5 \mathrm{ml}$ under reduced pressure at $40^{\circ} \mathrm{C}$. The concentrate $(0.5 \mathrm{ml})$ was placed in a test tube and evaporated to dryness; the residue was derivatized.

One $\mathrm{ml}$ of BP was applied directly to the ion exchange column.

\section{Derivatization of amino acids}

The amino acids were transformed into isopropyl-trifluoro-acetyl derivatives according to the method of Gobbetti et al (1993).

\section{Analysis of amino acids}

The amino acids were separated and quantified profile was obtained by gas chromatograph (Chrompack 9001; Middelburg, EA 4330, the Netherlands) with a split-splitless injector (in split mode, split ratio was $1: 30$ ), flame ionization detector on a 25-m x 0.25-mm Chirasyl-L-Val column (Chrompack) and an EMI 80386 computer, with MOSAIC integration software (Chrompack). The column oven was temperature programmed: $60^{\circ} \mathrm{C}$ (15 min), to $88^{\circ} \mathrm{C}$ at $1.5^{\circ} \mathrm{C} / \mathrm{min}$, at $88^{\circ} \mathrm{C}(6 \mathrm{~min})$, to $195^{\circ} \mathrm{C}$ at $2^{\circ} \mathrm{C} / \mathrm{min}$, and then held at $195^{\circ} \mathrm{C}$ for $15 \mathrm{~min}$. Other conditions were: injector and detection temperatures, $220^{\circ} \mathrm{C} ; \mathrm{H}_{2}$ flow rate, $20 \mathrm{ml} / \mathrm{min}$; $\mathrm{N}_{2}$ flow rate (make up), $20 \mathrm{ml} / \mathrm{min}$; air flow rate, $200 \mathrm{ml} / \mathrm{min}$; carrier gas $(\mathrm{He})$ head pressure, $780 \mathrm{~mm} \mathrm{Hg}$; and injection volume, ca $0.1 \mu \mathrm{l}$.

\section{Statistical analysis}

The results are the means of six replicates (three samples, each analysed twice); the data were subjected to analysis of variance (ANOVA) (Stanton, 1988).

\section{Aminopeptidase activity on BP}

$\mathrm{H}$-Leu-Trp-Met-Arg-Phe-OH and $\mathrm{H}$-Val-Pro-LeuLeu-OH (Bachem Feinchemikalien AG Products, Budendorf, Switzerland) were selected because the two peptides are part of the sequence of bitter peptides from $\alpha_{s 1}$-casein. Leu-Trp, corresponding to the $\alpha_{s 1}$ f198-199 was isolated by Hill and van Leeuwen (1974), while Miniamura et al (1972) isolated the bitter tetrapeptide Leu-Trp-Leu-Trp. Val-Pro-Leu is the initial sequence of the bitter peptide $\alpha_{s 1}$ f167-179 isolated by Pélissier et al (1974b). For the two peptides used in this study, the bitterness 'index' (Q-rule) of Ney is 2020 and 
$2420 \mathrm{cal} / \mathrm{res}$, respectively. The assay mixture contained $600 \mu \mathrm{l}$ of $0.05 \mathrm{~mol} / \mathrm{l}$ potassium phosphate buffer (KPB) $(\mathrm{pH} 7.0), 200 \mu$ l of peptide solution ( $2.5 \mathrm{mmol} / \mathrm{f}$ final concentration) and $200 \mu \mathrm{l}$ of aminopeptidase at a concentration of 0.05 units $/ \mathrm{ml}$. After incubation for 20,40 and $60 \mathrm{~min}$ at $37^{\circ} \mathrm{C}$, reaction was stopped with $0.1 \mathrm{~mol} / \mathrm{l}$ acetic acid.

\section{Aminopeptidase activity on BHMP}

In order to obtain BHMP, UHT skim milk was treated with a neutral endoprotease B500 from BacilIus amyloliquefaciens (Gist Brocades, Delft, the Netherlands). This protease was shown to produce bitter peptides (Piet et al, 1990). On the basis of preliminary assays, the sterile enzyme solution was added aseptically $(0.2 \mathrm{mg} / \mathrm{ml})$ to UHT skim milk ( $\mathrm{pH} 6.70$, protein $3.2 \%$, lactose $4.5 \%$ ) for $30 \mathrm{~min}$ at $55^{\circ} \mathrm{C}$. The endoprotease was desactivated by heating at $90^{\circ} \mathrm{C}$ for $10 \mathrm{~min}$. An internal laboratory panel confirmed the bitter taste of the BHMP. After this treatment, aminopeptidase at a concentration of 0.01 or 0.05 units $/ \mathrm{ml}$ BHMP was added and the mixtures were incubated at $37^{\circ} \mathrm{C}$ for $120 \mathrm{~min}$. The reaction was stopped by TCA precipitation and the samples were centrifuged as previously described. A comparison between the activity of 0.05 units $/ \mathrm{ml} \mathrm{BHMP}$ at 20 and $37^{\circ} \mathrm{C}$ for 60 and $120 \mathrm{~min}$ was conducted. The activity of 0.0025 units/ml BHMP was controlled at room temperature (range $12-20^{\circ} \mathrm{C}$ ) for 40 days (BHMP contained $0.02 \mathrm{w} / \mathrm{v}$ of $\mathrm{Na}$-Azide).

The aminopeptidase activity $(0.05$ units $/ \mathrm{ml})$ was also tested at $37^{\circ} \mathrm{C}$ for 120 min on unhydrolyzed UHT skim milk (control).

\section{Cheesemaking and determination of the aminopeptidase activity in cheese extract}

Two batches of Caciotta type cheese were manufactured in the laboratory plant (Battistotti et al, 1983). The liters of pasteurized $\left(16 \mathrm{~s} / 72^{\circ} \mathrm{C}\right)$ whole milk supplied with $0.1 \mathrm{~g} / \mathrm{l}$ of $\mathrm{CaCl}_{2}$ were used for each batch. Lactococcus lactis subsp lactis F103 and Streptococcus thermophilus I16 belonging to the Collection of the Dairy Microbiology Institute of Perugia were added to the milk at a $2.5 \%$ ratio $(v / v)$. After $30 \mathrm{~min}$ of incubation at $35^{\circ} \mathrm{C}$, the coagulant consisting on calf rennet extract ( $\mathrm{Chr}$
Hansens Laboratoty, Horsholm, Denmark) diluted $1: 100(\mathrm{w} / \mathrm{v})$ was added to the milk at a ratio of $1: 100(\mathrm{v} / \mathrm{v})$. After coagulation $\left(30 \mathrm{~min}\right.$ at $\left.35^{\circ} \mathrm{C}\right)$, curd cutting ( $2 \mathrm{~cm}$ grains) and whey drainage $\left(15^{\circ} \mathrm{C}, 18 \mathrm{~h}\right)$, the aminopeptidase $(5.5 \mathrm{units} / \mathrm{kg}$ curd) was dissolved in the salt solution $(8 \%, 3 \mathrm{~h}$ of salting) and added to the milled curd of the first batch of cheese while the second batch was untreated and considered as the control. The heating of Caciotta type cheese at $50^{\circ} \mathrm{C}$ was excluded in order to avoid loss of the enzymatic activity. The ripening was conducted for 2 months at $10^{\circ} \mathrm{C}(80 \%$ of relative humidity).

The aminopeptidase stability in the cheese was measured in the water soluble extract of cheeses prepared by the method of Desmazeaud and Vassal (1979). Aminopeptidase activity of the supernatants was measured by using Leu$\beta$ na-naphthylamide as a substrate (Gobbetti et al, 1994).

\section{Cheese analysis}

The $\mathrm{pH}$ was recorded in diluted $(1: 10)$ and homogenized samples. The total solids of cheese were determined on $5 \mathrm{~g}$ of grated cheese at $103^{\circ} \mathrm{C} \pm$ $2^{\circ} \mathrm{C}$ for $15 \mathrm{~h}$. Salt was determined by potentiometric method (Fox, 1963). Total protein and nonprotein nitrogen (NPN) were determined by the micro-Kjeldahl method. The NPN was obtained by adding trichloroacetic acid ( $12 \%$ final concentration) to the diluted $(1: 10)$ and homogenized samples.

\section{RESULTS AND DISCUSSION}

\section{Effect on bitter peptides (BP)}

The aminopeptidase from Pseudomonas fluorescens ATCC 948 completely hydrolyzed the H-Leu-Trp-Met-Arg-Phe-OH pentapeptide. Complete hydrolysis of Leu (2.5 $\mathrm{mmol} / \mathrm{l}$ represented $100 \%$ hydrolysis) was recorded after $20 \mathrm{~min}$ of incubation (fig 1), almost all Trp (2.45 mmol/l) and about $60 \%$ of the Met were released after $40 \mathrm{~min}$. High activity on Leu at $\mathrm{N}$-terminal confirmed the 


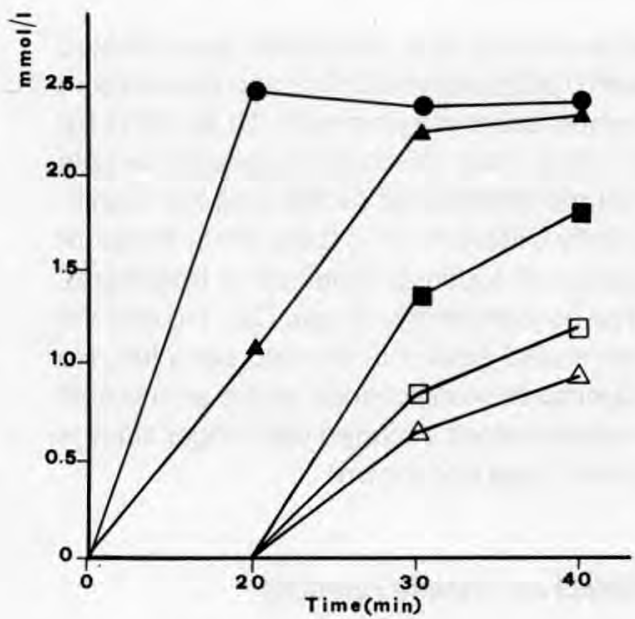

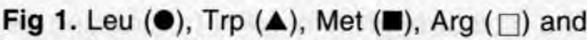
Phe $(\Delta)$ concentrations after hydrolysis of the pentapeptide H-Leu-Trp-Met-Arg-Phe-OH by the aminopeptidase from Pseudomonas fluorescens ATCC 948.

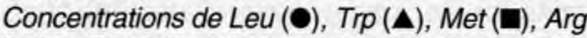
$(\square)$ et Phe $(\Delta)$ après hydrolyse du pentapeptide H-Leu-Trp-Met-Arg-Phe-OH par l'aminopeptidase de Pseudomonas fluorescens ATCC 948.

previously determined specificity of this enzyme (Gobbetti et al, 1994).

The hydrolysis of Val from the BP H-ValPro-Leu-OH was almost complete after $20 \mathrm{~min}$ (fig 2). However, only traces of Pro and Leu were detected after $3 \mathrm{~h}$ of treatment with aminopeptidase. The incapacity of this enzyme to cleave bound peptides involving Pro residue was confirmed (Gobbetti et al, 1994).

\section{Effect on bitter hydrolyzed of UHT milk proteins (BHMP)}

As used by others (Minagawa et al, 1989; Piet et al, 1990), the first step for studying the activity of the aminopeptidase on BHMP was to produce bitter peptides using $B$ amyIoliquefaciens neutral endoprotease B500.

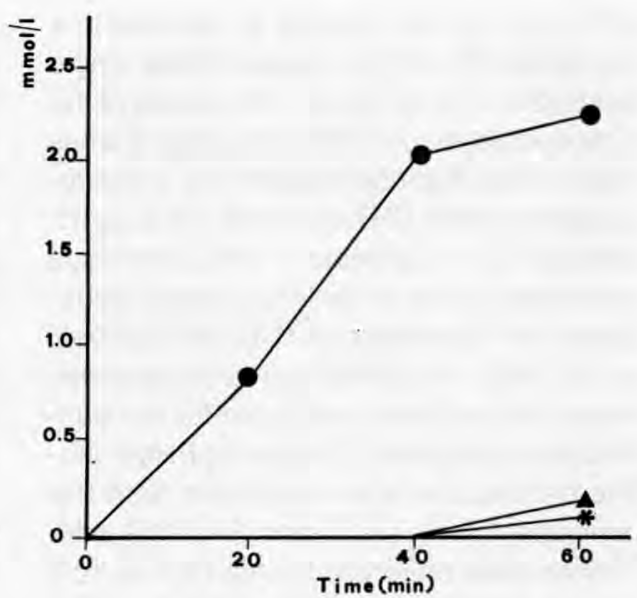

Fig 2. Val (O), Pro (A) and Leu (*) concentrations after hydrolysis of the tetrapeptide $\mathrm{H}-\mathrm{Val}$-ProLeu-Leu-OH by the aminopeptidase from Pseudomonas fluorescens ATCC 948.

Concentrations de Val (O), Pro (A) et Leu (*) après hydrolyse du tétrapeptide H-Val-Pro-LeuLeu-OH par l'aminopeptidase de Pseudomonas fluorescens ATCC 948.

BHMP contained a significantly $(P<0.05)$ higher concentration of free amino acids than the untreated UHT skim milk control (53 $\mu \mathrm{g} / \mathrm{ml}$, sample 2, vs $10.4 \mu \mathrm{g} / \mathrm{ml}$, sample 1). The extensive hydrolysis was due to endoprotease B500 and probably to a contamination of the commercial enzyme with aminopeptidase. After heating $\left(90^{\circ} \mathrm{C}\right.$ for $10 \mathrm{~min}$ ) BHMP, the concentration of free amino acids did not increase during $120 \mathrm{~min}$ at $37^{\circ} \mathrm{C}(60 \mu \mathrm{g} / \mathrm{ml}$, sample 4). The heating was necessary to avoid residual endoprotease $\mathrm{B} 500$ activity at $37^{\circ} \mathrm{C}$ (the free amino acid concentration increased from $53 \mu \mathrm{g} / \mathrm{ml}$, sample 2, to $82 \mu \mathrm{g} / \mathrm{ml}$, sample 3 ). The incubation of UHT skim milk at $55^{\circ} \mathrm{C}$ for $30 \mathrm{~min}$ and then at $37^{\circ} \mathrm{C}$ for $120 \mathrm{~min}$ did not significantly modify the amino acid concentration of sample 1 (data not shown). Treatment of BHMP with pseudomonad aminopeptidase (0.05 units/ml BHMP) at 
$37^{\circ} \mathrm{C}$ for $120 \mathrm{~min}$ (sample 8 ) resulted in a significant $(P<0.05)$ increase of free amino acids $(211.3 v s 53 \mu \mathrm{g} / \mathrm{ml})$. The activity of the aminopeptidase on BHMP was about 8 times higher than that observed on the unhydrolyzed non-bitter UHT skim milk $(25.3 \mu \mathrm{g} / \mathrm{ml}$, sample 5). In agreement with a previous characterization of cell-associated peptidases of $P$ fluorescens ATCC 948 (Gobbetti et al, 1993), the BHMP can also be considered as a suitable substrate for the purified aminopeptidase. Comparing BHMP profile before and after treatment with the aminopeptidase, significant $(P<0.05)$ differences were observed for Ala (3.8 vs 12.5 $\mu \mathrm{g} / \mathrm{ml})$, Glu (10.2 vs $55.6 \mu \mathrm{g} / \mathrm{ml})$, Leu (3.8 vs $51.2 \mu \mathrm{g} / \mathrm{ml})$, Met (0.1 vs $11.5 \mu \mathrm{g} / \mathrm{ml})$, Trp (3.5 vs $23.6 \mu \mathrm{g} / \mathrm{ml}$ ) and $\mathrm{Val}$ ( 3.5 vs 18.4 $\mu \mathrm{g} / \mathrm{ml})$. The increased concentration of Leu, Trp and Val reflected the specificity shown by synthetic BP. The specific accumulation of Leu, Met, Trp and Val, which usually appear as the major components of bitter peptides, probably indicated debittering of BHMP. As postulated by the $Q$ rule (Ney, 1979), the liberation of only one strongly bitter amino acid (Leu and Trp have high $Q$ values of 2420 and $3000 \mathrm{cal} / \mathrm{res}$, respectively) from a bitter sequence could generate a new nonbitter peptide. At $20^{\circ} \mathrm{C}$ (sample 9) the activity of the aminopeptidase at concentration of 0.05 units/ml BHMP also produced a significant $(P<0.05)$ increase of the amino acid content of BHMP (from 53 to $90.4 \mu \mathrm{g} / \mathrm{ml}$ ) (table I). The activity at this temperature was $44 \%$ of the maximum activity of this enzyme. Gobbetti et al (1994) determined that the enzyme shows $50 \%$ and $100 \%$ activity on Leu- $\beta$ na at 20 and $37^{\circ} \mathrm{C}$, respectively. An increase either of the amount of enzyme used from 0.01 to 0.05 units/ml BHMP (samples 6 and 7) or a longer incubation time from 60 to $120 \mathrm{~min}$ (samples 7 and 8 ) significantly increased $(P<0.05)$ the final concentration of the free amino acids.

To determine the potential activity of the aminopeptidase during the long-term sto- rage of UHT milk, the BHMP were treated with 0.0025 units/ml BHMP and kept at room temperature varying from 12 to $20^{\circ} \mathrm{C}$ for 40 days. After 25 days of storage (sample $10)$ the amino acid profile was not significantly different $(P<0.05)$ from those of sample 8 (optimal condition of treatment). The concentrations of Leu, Glu, Trp and Val were also similar in the two samples. No significant modifications of the amino acid concentrations occurred with longer storage times (data not shown).

\section{Effect on cheese ripening}

The moisture, protein, NPN (expressed as percentage of NPN/total nitrogen), salt and $\mathrm{pH}$ of the two cheeses produced are shown in table II. The levels were within normal limits for Caciotta cheese (Battistotti et al, 1983). There was no significant $(P<0.05)$ difference in cheese composition between the experimental and control batches after 1 day. The level of NPN increased from about $6 \%$ in the 1-day-old cheeses to about $14.5 \%$ after 60 days of ripening (fig 3 ). The content and rate of the NPN increase during ripening were not significantly $(P<0.05)$ dependent on the addition of aminopeptidase during manufacturing. However, the results illustrated in figure 3 indicate that the aminopeptidase-treated Caciotta type cheese exhibited a higher aminopeptidase activity throughout the ripening period. The level of aminopeptidase activity in the extract-treated cheese remained constant during 2 months. In contrast, the control cheese showed a low aminopeptidase activity on Leu$\beta$ na after only 15 days of ripening. The time necessary to reach this aminopeptidase activity could correspond to the extensive lysis of lactic acid bacteria starters during the first or second weeks of the ripening period (Law and Sharpe, 1975). Even though only $35 \%$ of the maximum activity was retained in acidic buffer (Gobbetti et al, 
1994), the stability of the aminopeptidase during Caciotta type ripening could have increased due to the divalent cations present in the cheese (Jarret, 1979). Confirming the important role of the intracellular aminopeptidases of lactic acid bacteria during cheese ripening (EI Abboudi et al,
1991), the amino acid profile of experimental and control Caciotta type cheese significantly $(P<0.05)$ differed after 45 days of ripening. The aminopeptidase from $P$ fluorescens ATCC 948 caused a higher accumulation of free amino acids (990.2 vs $571.1 \mu \mathrm{g} / \mathrm{ml}$ ). Compared to the not detec-

Table I. Free amino acid concentration in the 10 analyzed samples.

Concentration d'acides aminés libres dans les 10 échantillons analysés.

\begin{tabular}{|c|c|c|c|c|c|c|c|c|c|c|}
\hline $\begin{array}{l}\text { Amino } \\
\text { acids }\end{array}$ & 1 & 2 & 3 & 4 & ${ }_{\mu}^{5}$ & $m^{6}$ & 7 & 8 & 9 & 10 \\
\hline Ala & 0.5 & 3.8 & 5.9 & 4.2 & 1.1 & 5.4 & 7.6 & 12.5 & 5.3 & 16.3 \\
\hline Asp & 0.1 & 0.2 & 1.3 & 0.1 & 1.7 & 2.0 & 2.1 & 5.5 & 1.8 & 7.2 \\
\hline Cys & 0.1 & 0.1 & 0.5 & 0.1 & 0.1 & 0.8 & 1.2 & 0.7 & 1.3 & 0.5 \\
\hline Gly & 1.9 & 3.1 & 3.6 & 3.8 & 2.1 & 1.8 & 1.5 & 0.8 & 0.4 & 0.8 \\
\hline Glu & 1.3 & 10.2 & 18.6 & 12.2 & 2.7 & 22.5 & 31.1 & 55.6 & 17.4 & 60.4 \\
\hline Ile & 0.2 & 0.6 & 0.8 & 0.8 & 0.3 & 1.8 & 1.4 & 1.7 & 1.6 & 1.0 \\
\hline Leu & 0.6 & 3.8 & 3.5 & 3.8 & 3.6 & 18.8 & 25.5 & 51.2 & 23.2 & 58,7 \\
\hline Lys & 0.2 & 7.5 & 12.3 & 8.9 & 1.0 & 0.7 & 1.3 & 1.9 & 6.8 & 2.2 \\
\hline Met & 1.0 & 0.1 & 0.3 & 0.1 & 1.8 & 3.5 & 4.9 & 11.5 & 2.7 & 10.8 \\
\hline Phe & 0.5 & 6.8 & 10.3 & 7.9 & 1.8 & 0.5 & 2.5 & 4.7 & 1.0 & 3.8 \\
\hline Ser & 0.7 & 5.3 & 7.2 & 5.3 & 1.3 & 0.2 & 1.0 & 9.1 & 2.1 & 7.4 \\
\hline Thr & 0.5 & 2.2 & 3.5 & 3.4 & 1.3 & 1.5 & 2.8 & 4.3 & 1.7 & 3.7 \\
\hline Tyr & 1.4 & 4.0 & 7.4 & 4.1 & 2.5 & 1.5 & 2.8 & 9.8 & 2.1 & 4.8 \\
\hline Trp & 0.5 & 1.8 & 1.6 & 2.1 & 2.8 & 14.8 & 20.3 & 23.6 & 15.8 & 22.2 \\
\hline Val & 0.9 & 3.5 & 5.2 & 3.2 & 2.2 & 6.5 & 10.8 & 18.4 & 7.2 & 21.3 \\
\hline Total & 10.4 a & $53.0^{\mathrm{b}}$ & $82.0^{c}$ & $60.0^{b}$ & $25.3^{d}$ & $82.3^{c}$ & $116.8^{e}$ & $211.3^{f}$ & $90.4^{c}$ & $221.1^{f}$ \\
\hline
\end{tabular}

a,b,c,d,e,f Items in the total amino acids row followed by different superscript letters differ $(P<0.05) .1$, UHT skim milk; 2, UHT skim milk treated with B500 for 30 min at $55^{\circ} \mathrm{C}$ (BHMP); 3 , UHT skim milk treated with B500 for 30 min at $55^{\circ} \mathrm{C}$ and then incubated for $120 \mathrm{~min}$ at $37^{\circ} \mathrm{C} ; 4$, UHT skim milk treated with $\mathrm{B} 500$ for $30 \mathrm{~min}$ at $55^{\circ} \mathrm{C}$ and then incubated for $120 \mathrm{~min}$ at $37^{\circ} \mathrm{C}$ after heat-treatment; 5 , UHT skim milk treated with aminopeptidase $(0.05 \mathrm{units} / \mathrm{ml})$ from Pseudomonas fluorescens ATCC 948 for $120 \mathrm{~min}$ at $37^{\circ} \mathrm{C} ; 6$, BHMP treated with aminopeptidase $(0.01 \mathrm{units} / \mathrm{ml})$ for $60 \mathrm{~min}$ at $37^{\circ} \mathrm{C} ; 7$, BHMP treated with aminopeptidase $(0.05$ units $/ \mathrm{ml})$ for $60 \mathrm{~min}$ at $37^{\circ} \mathrm{C} ; 8$, BHMP treated with aminopeptidase $(0.05$ units $/ \mathrm{ml})$ for $120 \mathrm{~min}$ at $37^{\circ} \mathrm{C} ; 9$, BHMP treated with aminopeptidase $(0.05 \mathrm{units} / \mathrm{ml})$ for $120 \mathrm{~min}$ at $20^{\circ} \mathrm{C}$; 10, BHMP treated with aminopeptidase $(0.0025$ units $/ \mathrm{ml})$ for 25 days at room temperature.

$a, b, c, d, e, t$ Les items de la série totale des acides aminés suivis de lettres distinctes diffèrent $(P<0,05)$. $1=$ lait UHT écrémé ; 2 = lait UHT écrémé soumis à l'action de $\mathrm{B} 500$ pendant 30 min à $55^{\circ} \mathrm{C}(\mathrm{BHMP}) ; 3=$ lait UHT écrémé soumis à l'action de $B 500$ pendant $30 \mathrm{~min}$ à $55^{\circ} \mathrm{C}$, puis incubé pendant $120 \mathrm{~min}$ à $37^{\circ} \mathrm{C} ; 4=$ lait UHT écrémé soumis à l'action de $\mathrm{B} 500$ pendant $30 \mathrm{~min}$ à $55^{\circ} \mathrm{C}$, puis incubé pendant $120 \mathrm{~min}$ à $37^{\circ} \mathrm{C}$ après le traitement thermique ; $5=$ lait UHT écrémé soumis à l'action de l'aminopeptidase $(0,05$ unités $/ \mathrm{ml})$ de Pseudomonas fluorescens ATCC 948 pendant 120 min à $37^{\circ} \mathrm{C} ; 6=$ BHMP soumis à l'action de l'aminopeptidase $(0,01$ unités $/ \mathrm{ml})$ pendant $60 \mathrm{~min}$ à $37^{\circ} \mathrm{C} ; 7$ $=$ BHMP soumis à l'action de l'aminopeptidase $(0,05$ unités $/ \mathrm{ml})$ pendant $60 \mathrm{~min}$ à $37^{\circ} \mathrm{C} ; 8=B H M P$ soumis à l'action de l'aminopeptidase $(0,05$ unités $/ \mathrm{ml})$ de pendant $120 \mathrm{~min}$ à $37^{\circ} \mathrm{C} ; 9=B H M P$ soumis à l'action de l'aminopeptidase $(0,05$ unités $/ \mathrm{ml})$ pendant $120 \mathrm{~min}$ à $20^{\circ} \mathrm{C} ; 10=$ BHMP soumis à l'action de l'aminopeptidase $(0,0025$ unités $/ \mathrm{ml})$ de pendant 25 jours à température ambiante. 
Table II. Composition (\%) of Caciotta type cheeses made traditionally (control) and with the addition of the aminopeptidase from Pseudomonas fluorescens ATCC 948.

Composition (\%) de fromages du type Caciotta fabriqués de façon traditionnelle (contrôle) et avec addition de l'aminopeptidase de Pseudomonas fluorescens ATCC 948.

\begin{tabular}{lccccc}
\hline Cheese type & Moisture & Protein & NPN/TN & Salt & $p H$ \\
\hline Control & 36.35 & 26.38 & 5.90 & 1.82 & 5.31 \\
Aminopeptidase addition & 36.82 & 26.75 & 6.10 & 1.72 & 5.28
\end{tabular}

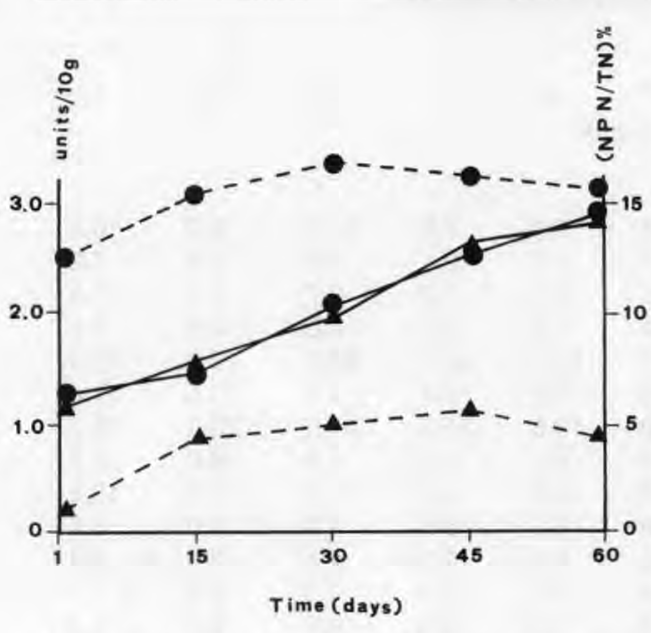

Fig 3. Stability of the aminopeptidase activity (units $/ 10 \mathrm{~g}$ of d.w. cheese) (-- ) and evolution of NPN/TN (\%) (-) in Caciotta type cheese made traditionally (control) $(\mathbf{\Delta})$ and with the addition of aminopeptidase from Pseudomonas fluorescens ATCC $948(\bullet)$.

Stabilité de l'activité de l'aminopeptidase (unités/10 g de fromage $p d s \mathrm{sec}$ ) (---) et évolution du rapport azote non protéique / azote total (\%) $(-$ dans le fromage du type Caciotta fabriqué de façon traditionnelle (contrôle) ( $\mathbf{\Delta})$ et avec addition de l'aminopeptidase (†) de Pseudomonas fluorescens ATCC 948.

table influence of the aminopeptidase on the NPN, the increase of free amino acids content can be attributed either to differences on the sensitivity of the two analytical methods or to the relevant hydrolysis of peptides (included on NPN) to produce free amino acids. No significant variations were observed after further 15 days of ripening (data not shown). As far as the aminopeptidase activity on BHMP is concerned, the highest differences were attributed to Glu (213.7 vs $126.5 \mu \mathrm{g} / \mathrm{ml})$, Leu (306.2 vs $198.9 \mu \mathrm{g} / \mathrm{ml})$, Met $(65.7$ vs $33.6 \mu \mathrm{g} / \mathrm{ml})$, Trp (79.7 vs $37.8 \mu \mathrm{g} / \mathrm{ml}$ ) and $\mathrm{Val}(77.6 \mathrm{vs}$ $42.0 \mu \mathrm{g} / \mathrm{ml}$ ). This specific aminopeptidase activity during cheese ripening indicated the potential to hydrolyze peptides and probably bitter peptides generated by the combined action of rennet and bacterial proteolytic enzymes. Use of non-starter aminopeptidase preparations to reduce bitterness in cheese was proposed earlier (Roncari and Zuber, 1970; Brezina et al, 1988; Minagawa, 1989). Malkki (1978) and Malkki et al (1979) found that a strain of $P$ fluorescens produced a complex of endopeptidases and exopeptidases that converted 60 to $90 \%$ of the milk proteins to free amino acids. In particular, bitterness was absent when peptidases from $P$ fluorescens VTTE 1.8 were added to Edam-type cheese (Malkki, 1978); the enzyme preparation also prevented bitterness and enhanced the ripening process of Cheddar-type cheese made with calf rennet (Malkki et al, 1979). Our studies indicated that aminopeptidase from $P$ fluorescens ATCC 948 has promising specificity for degrading bitter peptides.

Presence of D-amino acid isomers was reported for various dairy products and was also attributed to microbial activity (Bruckner and Hausch, 1990; Gobbetti et al, 1994). In 
Table III. Amino acid profiles of Caciotta type cheeses made traditionally (control) and with the addition of aminopeptidase from Pseudomonas fluorescens ATCC 948 during ripening.

Profils des acides aminés de fromages du type Caciotta fabriqués de façon traditionnelle (contrôle) et avec addition de l'aminopeptidase de Pseudomonas fluorescens ATCC 948 pendant l'affinage.

\begin{tabular}{|c|c|c|c|c|c|}
\hline \multicolumn{2}{|c|}{ Amino acids } & 1 & \multicolumn{2}{|c|}{$\mu g / m l$} & 4 \\
\hline \multirow{2}{*}{ Ala } & $\mathrm{L}$ & 2.1 & 2.8 & 7.6 & 22.7 \\
\hline & D & & & 8.5 & 8.0 \\
\hline \multirow{2}{*}{ Asp } & & 1.2 & 1.0 & 9.4 & 7.1 \\
\hline & & & & 1.6 & 0.9 \\
\hline \multicolumn{2}{|l|}{ Cys } & 0.1 & 0.1 & 0.3 & 0.3 \\
\hline \multicolumn{2}{|l|}{ Gly } & 3.2 & 2.5 & 11.6 & 18.7 \\
\hline \multirow[t]{2}{*}{ Glu } & L & 7.8 & 8.7 & 106.5 & 213.7 \\
\hline & D & & & 14.5 & 11.3 \\
\hline \multicolumn{2}{|c|}{ Ile } & 1.2 & 1.6 & 6.0 & 18.9 \\
\hline \multicolumn{2}{|l|}{ Leu } & 8.7 & 10.2 & 178.9 & 306.2 \\
\hline \multirow[t]{2}{*}{ Lys } & L & 0.2 & 0.7 & 44.4 & 38.8 \\
\hline & D & & & 39.4 & 41.2 \\
\hline \multirow{2}{*}{ Met $L$} & & 0.7 & 0.7 & 33.6 & 65.7 \\
\hline & & & & & 0.5 \\
\hline \multirow[t]{2}{*}{ Phe } & $\mathrm{L}$ & 8.1 & 6.9 & 3.8 & 11.9 \\
\hline & D & & & 5.2 & 3.7 \\
\hline \multicolumn{2}{|c|}{ Ser } & 0.7 & 2.1 & 12.8 & 23.8 \\
\hline \multicolumn{2}{|l|}{ Thr } & 1.2 & 1.3 & 7.6 & 12.3 \\
\hline \multirow{2}{*}{ Tyr } & L & 0.4 & 0.6 & 10.2 & 14.3 \\
\hline & D & & & 9.4 & 12.9 \\
\hline \multicolumn{2}{|c|}{ Trp } & 1.8 & 1.9 & 27.8 & 79.7 \\
\hline \multicolumn{2}{|l|}{ Val } & 2.6 & 3.4 & 32.0 & 77.6 \\
\hline \multicolumn{2}{|c|}{ Total } & $40.0^{a}$ & $44.5^{a}$ & $571.1^{\mathrm{b}}$ & $990.2^{c}$ \\
\hline
\end{tabular}

particular, average concentrations of D-Ala $(8.2 \mu \mathrm{g} / \mathrm{ml})$, D-Glu $(12.9 \mu \mathrm{g} / \mathrm{ml})$, D-Lys $(40.3 \mu \mathrm{g} / \mathrm{ml})$ and D-Tyr $(11.1 \mu \mathrm{g} / \mathrm{ml})$ were detected in control and experimental Caciotta type cheese, indicating that the addition of pseudomonad aminopeptidase did not affect the isomerization process.

The broad specificity, the high activity on bitter peptides with hydrophobic amino acids at the $\mathrm{N}$ terminus, and the stability to acidic conditions propose the aminopeptidase from $P$ fluorescens ATCC 948 as a debittering enzyme to use as additive in various dairy produtcs. Because of the ability of Pseudomonas spp proteinases to generate bitter peptides and because of the physiological ability of the peptidases of the same microorganism to cleave the peptides produced by its own proteinases, the aminopeptidase considered in this study may have a specific aptitude to remove the bitter flavour in milk products. Genetic engineering or 
technological solutions must be considered in order to use this heat-sensitive aminopeptidase in UHT milk.

Further work is currently being carried out in order to evaluate the treated dairy products by sensory analysis and to determine a chemometric model for the aminopeptidase application.

\section{ACKNOWLEDGMENTS}

MG thanks Prof L Stepaniak (Department of Food Science of the Agricultural Faculty of Norway) for the useful revision of the manuscript. The authors thank F Bonomi for the skilled technical assistance.

\section{REFERENCES}

Ardo Y, Larson PO, Mansson HL, Hedenberg A (1989) Studies of peptidolysis during early maturation and its influence on low-fat cheese quality. Milchwissenschaft 44, 485-490

Arora G, Lee BH (1990) Comparative studies on peptidases of Lactobacillus casei subsp casei. I Dairy Sci $73,264-273$

Battistotti B, Bottazzi V, Piccinardi A, Volpato G (1983) Formaggi nel mondo. Mondadori, Milan, Italy

Bucky AR, Hayes PR, Robinson DS (1988) Enhanced inactivation of bacterial lipases and proteinases in whole milk by a modified ultra high temperature treatment. J Dairy Res 55, 373-380

Brezina P, Cikanek D. Plockova M, Schovankova I, Kopecny J (1988) Properties and degradation of bitter peptides in cheese. Prumysl Potravin 39, 303308

Bruckner H, Hausch M (1990) D-amino acids in dairy products: detection, origin and nutritional aspects. I. Milk, fermented milk, fresh cheese and acid curd cheese. Milchwissenschaft 45, 357-360

Delformo G, Parpani G (1986) Bitter flavours in cheese. Mondo Latte 40, 565-567

Desmazeaud MJ, Vassal L (1979) Activité protéolytique intracellulaire de streptocoques lactiques mésophiles. Role au cours de l'affinage des fromages. Lait 59 , $327-344$

Edwards JL Jr, Kosikoski FV (1983) Bitter compounds from Cheddar cheese. J Dairy Sci 66, 727-734

El Abboudi M, El Soda M, Pandian S, Bassean M, Trepanier G. Simard R (1991) Peptidase activities in debittering and nondebittering strains of lactobacilli. Int Dairy $J 1,55-64$

Fox PF (1963) Potentiometric determination of salt in cheese. J Dairy Sci 46, 744-749

Fox PF (1988) Rennets and their action in cheese manufacture and ripening. Biotechnol Appl Biochem 10, 522-535

Fujimaki M, Yamashita M, Okazawa Y, Arai S (1970) Applying proteolytic enzyme on soybean. 3 . Diffusable bitter peptides and free amino acids in peptic hydrolyzate of soybean protein. J Food Sci 35, 215218

Gobbetti M, Rossi J (1992) Peptidase profile of Pseudomonas fluorescens: identification and properties. J Dairy Sci 75, 924-934

Gobbetti M, Magnarini C, Rossi J, Cossignani L, Damiani $P$ (1993) Free D- and L-amino acids from hydrolyzed milk proteins by Pseudomonas fluorescens ATCC 948. J Dairy Sci 76, 2500-2506

Gobbetti M, Corsetti A, Fox PF (1994) Purification and characterization of an intracellular aminopeptidase from Pseudomonas fluorescens ATCC 948. J Dairy Sci, in press

Hill RD, Van Leeuwen H (1974) Bitter peptides from hydrolyzed casein coprecipitate. Aust J Dairy Technol 29, 32-34

Jarret WD (1979) A review of the important trace elements in dairy products. Aust $J$ Dairy Technol 34 , 28-35

Kamaly KM, Marth EH (1988) Proteinase and peptidase activities of cell-free extracts from mutant strains of lactic streptococci. J Dairy Sci 71, 2349-2357

Law BA, Sharpe ME (1975) Lactic acid bacteria and flavours in cheeses. In: Lactic Acid Bacteria Beverages and Food (JC Carr, CV Cutting, GC Whiting, eds) Academic Press, London

Lemieux L, Simard RE (1991) Bitter flavour in dairy products. I. A review of the factors likely to influence its development, mainly in cheese manufacture. Lait $71,599-636$

Lemieux L, Simard RE (1992) Bitter flavours in dairy products. II. A review of bitter peptides from caseins: their formation, isolation and identification, structure masking and inhibition. Lait 72, 335-382

Malkki Y (1978) Ripening and debittering of cheeses and protein hydrolysates. In: Fifth Int Congr Food Sci Technol (abstract) Kyoto Japan, 231

Malkki Y, Mattsson R, Markkanen P, Lindroth S, Karaila P (1979) Production and utilization of Pseudomonas fluorescens peptidases. In: Second International Congress on Engineering and Food and the Eight European Food Symposium (proceedings), Espoo, Finland, 282-288

McKellar RC (1981) Development of off-flavors in ultrahigh temperature and pasteurized milk as a function of proteolysis. J Dairy Sci 64, 2138-2145 
Minagawa E (1989) Characterization and utilization of thermostable exopeptidase. Jpn J Dairy Food Sci $6,259-266$

Minagawa E, Kaminogawa S, Tsukasaki F, Yamacki K (1989) Debittering mechanism in bitter peptides of enzymatic hydrolysates from milk casein by aminopeptidase. J Food Sci 54, 1225-1229

Miniamura N, Matsumura Y, Yamamoto T (1972) Bitter peptides in casein digests with bacterial proteinases. II. A bitter peptide consisting of tryptophane and leucine. J Biochem 72, 841-848

Ney KH (1979) Bitterness of peptides: amino acid composition and chain length. Food Taste Chem 1, 150173

Pélissier JP, Mercier JC, Ribadeau-Dumas B (1974a) Problème de l'amertume dans le fromage - résultats d'une enquête. Rev Lait Fr 325, 231-233

Pélissier JP, Mercier JC, Ribadeau-Dumas B (1974b) Etude de la protéolyse des caséines $\alpha_{\mathrm{s} 1}$ et bovines par la présure. Ann Biol Anim Biochim Biophys 14, 343-362
Piet MPJ, deRoss AL, Bommele MWC, Oosterom E, Persoon NLM (1990) Characterization of debittering activities of Lactococcus lactis. In : XXIII Int Dairy Congr (brief communications) Montréal 174

Roncari G, Zuber H (1970) Thermophilic aminopeptidases, AP1 from Bacillus stearothermophilus. Methods Enzymol 19, 544-560

Skura BJ (1989) Standards, control and future outlook. In: Enzymes of psychrotrophs in raw milk (McKellar RC, ed) CRC Press, Boca Raton, Florida, USA

Sørhaug T, Stepaniak L (1993) Microbial enzymes in the spoilage of milk and dairy products. In: Food Enzymology (Fox PF, ed) Elsevier, London

Stanton AG (1988) Statistica per discipline biomediche. McGraw-Hill, Milan, Italy

Visser S, Slangen KJ, Hup G, Stadhouders J (1983) Bitter flavours in cheese. 3. Comparative gel-chromatographic analysis of hydrophobic peptide fractions from twelve Gouda-type cheeses and identification of bitter peptides isolated from a cheese made with Streptococcus cremoris strain HP. Neth Milk Dairy $J$ 37, 181-192 